\title{
Vuorovaikutus opettajaksi opiskelevien asiantuntijuudessa
}

\author{
Emma Kostiainen \& Maija Gerlander
}

\section{Tiivistelmä}

Opettajan työssä vuorovaikutus on olennainen osa asiantuntijaosaamista. Työ toteutuu enimmäkseen vuorovaikutussuhteissa oppijoiden, opettajien, koulun muun henkilökunnan, vanhempien ja muiden sidosryhmien kanssa. Työssä korostuvat yhteistoiminta ja yhteisöllisyys: opettajan asiantuntijuus on vahvasti vuorovaikutusprosesseihin, -suhteisiin ja niihin osallistumiseen liittyvä ilmiö. Vuorovaikutuksen ja asiantuntijuuden yhteyden ymmärtäminen ei ole kuitenkaan itsestään selvää. Näin ollen on tärkeää tarkastella, miten opettajaksi opiskelevat näkevät vuorovaikutuksen merkityksen oman kehittyvän asiantuntijuutensa toteutumisessa.

Tässä artikkelissa tarkastellaan, millaisia merkityksiä luokanopettajaksi opiskelevat $(\mathrm{N}=127)$ antavat vuorovaikutukselle opintojen loppuvaiheeseen sijoittuvan asiantuntijuusseminaarin itsearvioinneissa. Asiantuntijuusseminaarin tarkoituksena on kehittää opettajaksi opiskelevien kykyä ymmärtää vuorovaikutuksen ja sen laadun merkitys asiantuntijuuden jakamisessa. Tässä opintojaksoa tarkastelevassa tutkimuksessa selvitetään, miten orientaatio vuorovaikutukseen (osallistuminen, jakaminen, prosessimaisuus) näkyy ja miten se ymmärretään opettajaksi opiskelevien itsearvioinneissa. Lisäksi tutkimuksessa selvitetään, millaisia suhtautumistapoja opiskelijoiden itsearvioinneissa ilmenee vuorovaikutukseen pohjautuvaa opintojaksoa kohtaan.

Artikkelissa nostetaan esille, miten opettajan asiantuntijuus ja siihen kasvaminen vaatii jo opiskeluaikana tietoista ja tavoitteellista vuorovaikutukseen ja yhteiseen jakamiseen perustuvaa orientaatiota ja ohjausta.

Asiasanat: asiantuntijuus, jakaminen, opettaja, opettajankoulutus, oppimisprosessi, vuorovaikutus

\section{Johdanto}

Vuorovaikutus kietoutuu opettajan asiantuntijuuteen monella tasolla: se on sekä asiantuntijuuden rakentamisen ja jakamisen väline että yksi asiantuntijuuden 
ulottuvuus. Vuorovaikutus yltää pienimmistäkin opetustilanteen viestintään liittyvistä yksityiskohdista (esim. opettajan nonverbaalinen viestintä) laajoihin, koko opettajaprofessiota läpileikkaaviin kysymyksiin (esim. opettajuuden määrittäminen moniammatillisessa asiantuntijayhteisössä). Asiantuntijuuden ja vuorovaikutuksen yhteyksien näkeminen ei ole kuitenkaan itsestään selvää ja helppoa.

Ymmärrämme viestinnän ja vuorovaikutuksen toisiinsa läheisesti kytkeytyvinä käsitteinä. Vuorovaikutuksella tarkoitamme tässä artikkelissa viestintäprosessiin osallistuvien välisiä, toisiinsa vaikuttavia tekoja tai toimintoja (ks. esim. Gerlander \& Kostiainen 2005, 70). Vuorovaikutuksen tutkimisessa kiinnostavia ovat esimerkiksi ne viestinnän keinot, tavat ja strategiat, joilla yksilöt ilmentävät ja tuottavat suhdettaan, positiotaan muihin. Se, millaisen merkityksen opettaja tai opettajayhteisö vuorovaikutukselle antaa, on hyvin tärkeää työssä menestymisen, jaksamisen ja kehittymisen kannalta. Vuorovaikutukselle annettuja merkityksiä voidaan pitää osana vuorovaikutusosaamista, erityisesti sen metakognitiivista ulottuvuutta (ks. Kostiainen 2003, 10; Valkonen 2003, 26).

Opettajien vuorovaikutusta tarkastellaan usein hyvin luokkahuonekeskeisenä, opettaja-oppilassuhteeseen painottuvana ilmiönä. Esimerkiksi puheviestinnän alalla on melko vähän tutkittu vuorovaikutusta opettajien keskinäisen ja muiden sidosryhmien asiantuntijuuden jakamisen näkökulmasta. Välijärvi $(2006,21)$ toteaa, että opettajan työ on jatkuvaa älyllistä, sosiaalista ja emotionaalista vuorovaikutusta oppilaiden, kollegoiden ja vanhempien kanssa. Työssä korostuu aikaisempaa enemmän yhteistoiminta ja yhteisöllisyys: opettajan tulisi luopua yksin selviämisen eetoksesta ja oppia keskustelemaan opetustyöstä työtovereiden ja muiden koulun työskentelyyn osallistuvien ammattiryhmien kanssa (Välijärvi 2006, 23; ks. myös Rautiainen 2008). Näin ollen opettajalta edellytetään oman osaamisen esille tuomista erilaisissa tilanteissa ja eri ihmisten kanssa toimittaessa (Tynjälä 2004), vahvaa ryhmäosaamista, uskoa ja luottamusta omaan asiantuntijuuteen ja siinä kehittymiseen sekä valmiutta nähdä asiantuntijuus erityisesti yhteisöllisenä, vuorovaikutuksessa rakentuvana, ei pelkästään yksilöllisenä piirteenä.

Vuorovaikutuksen merkitystä korostaa myös opettajan työtä nykyisin leimaava epävarmuus (Laine 2004, 53). Vaikka opettajan työssä tietyt vahvat ajatustraditiot tai juridiset reunaehdot (esim. opetussuunnitelma, virka- ja vaitiolovelvollisuudet) luonnollisestikin osaltaan määrittelevät opettajan asiantuntijuutta, on opettajuus yhä vahvemmin avointa asiantuntijuutta, jossa sen perusteet ja ehdot ovat huojuvia ja epämääräisiä sekä vuorovaikutukselle ja kyseenalaistamiselle antautuvia (ks. Eräsaari 2002, 23-30). Opettajan asiantuntijuus onkin yhä enemmän myös uskallusta jäädä neuvottomaksi ja pyytää apua, rohkeutta tarttua asioihin, joihin ei ole vastauksia sekä edellisten seikkojen aiheuttaman epämukavan ja epävarmuuden tunteen sietämistä. Näin ajatellen opettajan asiantuntijuus ja siihen kasvaminen vaatii jo opiskeluaikana tietoista ja 
tavoitteellista vuorovaikutukseen ja yhteiseen jakamiseen perustuvaa orientaatiota: ajattelutapojen testaamista, vertaamista, kyseenalaistamista ja edelleen kehittelyä yhdessä toisten kanssa (ks. myös Hurma 2009).

Katsomme, että tarkoituksenmukaista vuorovaikutusorientaatiota on mahdollista rakentaa erityisesti koulutuksen aikana. Artikkelissa tarkastelemmekin, miten luokanopettajaopiskelijat näkevät vuorovaikutuksen merkityksen oman kehittyvän asiantuntijuutensa toteutumisessa. Näyttääkö asiantuntijuus kiinnittyvän enemmän yksilöön vai yksilöiden välisiin vuorovaikutussuhteisiin. Lisäksi tarkastelemme, millaisia suhtautumistapoja tutkimuksen kontekstina oleva opintojakso ja sen toteutustapa herättävät. Tutkimuksen kohteena ovat Jyväskylän yliopiston luokanopettajaksi opiskelevien itsearvioinnit, jotka he kirjoittivat opintojen loppuvaiheeseen sijoittuvan asiantuntijuusseminaarin jälkeen.

\section{Asiantuntijuus osallistumisena tietämysverkostoihin}

Asiantuntijaksi kehittymistä tarkastellaan tyypillisesti niin, että muodollinen koulutus ei itsessään valmista kenestäkään asiantuntijaa vaan että asiantuntijuus kehittyy vasta työyhteisössä käytännön ongelmanratkaisutilanteissa, asiantuntijayhteisön toimintaan osallistumalla (ks. Hakkarainen 2000; 2005). Sitä ei nähdä yksilön pään sisäisenä prosessina, vaan sosiaalisesti hajautuneena sekä kulttuurisiin toiminnan välineisiin ankkuroituneena (Hakkarainen \& Paavola 2007, 226-227). Yhteisöllisestä näkökulmasta katsottuna asiantuntijaksi kehittyminen nähdäänkin asteittain syvenevinä osallistumisen prosesseina, joissa oppija voi aitoihin asiantuntijakäytäntöihin (esim. harjoitteluun) osallistumalla vähitellen omaksua asiantuntijatyön hiljaista tietoa ja toimintakulttuuria (Hakkarainen \& Paavola 2007, 235).

Asiantuntijaksi kehittymisen kannalta olennaista on se, miten liittyminen tietämysverkostoihin tapahtuu erilaisissa vuorovaikutussuhteissa. Nämä prosessit vaikuttavat siihen, mitä ja miten oppija oppii (ks. Wenger 1999; Eteläpelto ym. 2005). Koska asiantuntijuus opetuksen alueella on pitkä ja haastava prosessi (Bullough \& Baughman 1995), on tärkeää, että opiskelija oppii jo opintojensa aikana näkemään itsensä kehittyvänä asiantuntijana. Tässä mielessä voi opettajaksi opiskelevan asiantuntijaksi kasvua katsoa eri tavoin kuin monilla muilla aloilla. Jo koulutuksen aikana opettajan asiantuntijuuteen on mahdollista saada tuntumaa, koska opiskelija on jo valmiiksi osallisena oman alansa käytännön työyhteisössä ja mitä erilaisimmissa oppimisprosesseissa. Työyhteisön jäsenyyteen pääsemistä ei varsinaisesti tarvitse odottaa. Tämä potentiaali on vain osattava tarkoituksenmukaisesti hyödyntää opettajankoulutuksessa - oppimisprosessit itsessään on valjastettava hyötykäyttöön ja tehtävä entistä tietoisemmiksi ja näkyvämmiksi. Myös tutkimustietoa osallistumisprosessien liittymisestä oppimiseen tarvitaan (ks. esim. Hakkarainen 2000, 86; Eteläpelto ym. 
2005). Kun otetaan huo-mioon opettajan työn vuorovaikutuksellinen luonne ja vuorovaikutuksen merkitys asiantuntijaksi kehittymisessä, on olennaista pohtia, millainen ajattelutapa vuorovaikutuksesta opitaan opettajankoulutuksessa.

\section{Opettajaksi opiskelevan näkökulmat opettajan asiantuntijuuteen}

Opetus- ja kasvatusalan asiantuntijaksi kehittyminen on lähtökohdiltaan erilaista kuin esimerkiksi insinööri- tai hammaslääketieteen asiantuntijaksi kehittyminen: opetuksen ja oppimisen prosessit itsessään ovat samalla sekä asiantuntijuuden oppimisen menetelmä että oppimisen kohde. Opettajaksi opiskelevalla oppimisen ja opiskelun kohde on samalla prosessi, jonka avulla hänen tavoitteenaan on kehittyä tuon samaisen prosessin asiantuntijaksi. Näin hän myös tarkastelee erilaisten ammatillisten suhteiden vuorovaikutusta (kohde) vuorovaikutuksessa (prosessi) ja pyrkii oppimaan siitä sekä kohteena että prosessina.

Oman asiantuntijuuden kenttä avautuu opetusalalla työskentelevälle kolmesta omakohtaisesti koetusta näkökulmasta: oppilaan, opiskelijan ja opettajan. Opettajaksi opiskeleva on jo koulutukseen tullessaan ollut vuosikausien ajan tiiviisti osallisena tulevan asiantuntijuusalansa prosesseissa oppilaan roolissa. Hän on myös koulutuksensa aikana opiskelijan roolissa jatkuvasti osallisena niissä prosesseissa, joiden analyyttiseksi ja kriittiseksi asiantuntijaksi hänen tulisi kasvaa. Valmistuneen opettajan roolissa työ ja asiantuntijuus edellyttävät samaa kuin ne prosessit, joihin opettajaksi opiskeleva on koko edeltävän koulutusuransa aikana osallistunut.

Jotta nämä edellä kuvatut näkökulmat opettajuuteen eivät sekoitu keskenään ja niitä pystytään analyyttisesti tarkastelemaan, on opettajaksi opiskelevalla oltava reflektointikykyä ja vuorovaikutusosaamista. Hänen on kyettävä asettumaan joustavasti erilaisiin reflektiivisiin näkökulmiin ja tiedostamaan kulloinenkin positionsa. Vahva kokijan tieto omasta tulevasta alasta vaikuttaa opiskeluun eri tavoin kuin muilla aloilla. Ei liene olemassa muuta alaa, jossa ammattiin opiskelevalla olisi ollut yhtä tiivis "ammatillinen" kontakti tulevaan alaansa kuin opettajan ammatti. Koska työ tuntuu tutulta, vaatii se itse asiassa erityisen paljon ajattelun avartamista ja ennakkokäsitysten purkamista. Ajattelun avartaminen ja ennakkokäsitysten purkaminen vaativat puolestaan vuorovaikutusta. Ne nostavat myös itse vuorovaikutuksen reflektion kohteeksi. Oppimisprosessien tulisi opettajankoulutuksessa olla sellaisia, että ne tarjoaisivat monipuolisia työkaluja vuorovaikutuksessa tapahtuvan reflektion tueksi. 


\section{Vuorovaikutuksen ja asiantuntijuuden kytkennät opettajankoulutuksessa}

Opettajankoulutuksessa tarjottavaa viestintään ja vuorovaikutukseen liittyvää koulutusta koskevassa keskustelussa ongelmana on mielestämme usein se, että lääkkeeksi puutteelliseen koulutukseen tarjotaan täsmäkursseja viestinnästä (ks. esim. Hunt, Simonds \& Cooper 2002) eli erillisiä viestintään ja vuorovaikutukseen sisällöllisesti painottuvia kursseja. Asiantuntijuutta tällä tavoin viipaloivan orientaation sijaan vuorovaikutukseen liittyviä ilmiöitä tulee opetuksessa tarkastella laajemmissa konteksteissaan. Vuorovaikutus on nähtävä työtoiminnan perustasona, joka on läheisesti sidoksissa asiantuntijuuden ja opiskeltavan alan sisältöihin, identiteettiin ja epistemologiaan (Dannels 2001, 148; Kostiainen 2003; ks. myös Karila, Alasuutari, Hännikäinen, Nummenmaa \& Rasku-Puttonen 2006). Tällä tavoin vuorovaikutus sitoutuu osaksi aitoja työkäytänteitä.

Oppimisen siirrettävyyttä koskevissa tutkimuksissa päädytään usein havaintoon, että erilaisissa opetustilanteissa opittua asiantuntijatietoa ei useinkaan käytetä opetustilanteiden ulkopuolisissa vastaavissa konteksteissa (ks. esim. Alexander \& Murphy 1999; Renkl, Mandl \& Gruber 1996). Opitun siirtovaikutus ei ole kovinkaan spontaania tai automaattista, vaan siihen tarvitaan ohjausta. On todettu, että transferin syntymisessä olennaista on juuri oppimisprosessi - se miten tietoja, taitoja ja osaamisen kehittymistä on ohjattu ja miten niitä on opittu. (Ks. esim. Brown 1998, 168; Gruber ym.1996, 168.) Muusta koulutuskokonaisuudesta irrallisten viestintä- tai vuorovaikutuskurssien järjestämisen sijaan on olennaisempaa huolehtia siitä, että kurssien oppimisprosessi olisi itsessään samankaltainen kuin millaisena se opiskeltavan alan asiantuntijuuden ja vuorovaikutuksen integroinnin näkökulmasta on tarkoituskin oppia ymmärtämään. Tämä tukisi opitun soveltamista opetustilanteen ulkopuolelle.

Opiskelijan oppimisen kannalta ei ole tarkoituksenmukaisinta selittää tai kuvata, millä tavalla viestitään "ammatillisesti" listaamalla erilaisia työssä mahdollisesti eteen tulevia viestintätilanteita tai työssä tarvittavia vuorovaikutustaitoja. Sen sijaan vuorovaikutusosaamisen kehittymisen tukeminen tulisi toteuttaa niin, että oppija saa kokemuksen prosessista ja siitä kokonaisuudesta, jossa ja josta on tarkoitus oppia ja johon käsiteltäviä ilmiöitä ja tietoa voi suhteuttaa. Tällöin opiskelijoita voidaan jo koulutuksen aikana ohjata löytämään vuorovaikutukselle tarkoituksenmukaisia ja jäsentyneitä merkityksiä erilaisissa työtehtävissä. (Kostiainen 2003, 246-247.)

Asiantuntijuusseminaarin oppimisprosessin kuvaus. Asiantuntijuusseminaari (OKLV220 Äidinkielen viestintä ja vuorovaikutusosaaminen 2) on Jyväskylän yliopiston opettajankoulutuslaitoksessa opintojen loppuvaiheessa toteutettava kieli- ja viestintäopintoihin kuuluva opintojakso. Opintojaksoon on pyritty luomaan ja suunnittelemaan vuorovaikutus- ja kasvatusalan osaamisen integrointia mahdollisimman tarkoituksenmukaisella tavalla edistäviä oppimistehtäviä ja -tilanteita. Kahden opintopisteen laajuinen opintokokonaisuus muo- 
dostuu itsenäisestä (yksin ja ryhmässä tehtävästä) työskentelystä ja asiantuntijuusseminaariin osallistumisesta (ks. seuraavalla sivulla oleva kuvio 1).

Tavoitteena on toteuttaa opintojakso niin, että siinä havainnollistuu mahdollisimman tehokkaasti idea asiantuntijuudesta yhdessä rakennettuna eli osallistumisena tietämystä rakentaviin ja sitä luoviin verkostoihin. Opintojakso on rakennettu kolmen tausta-ajatuksen varaan: a) omaan asiantuntijayhteisöön sosiaalistuminen ja osallisuus yhteistyöverkostoissa toteutuvat vuorovaikutuksessa, b) opintojakson tavoitteet, sisällöt, toteutustapa ja arviointi tukevat toisiaan ja c) ryhmää hyödynnetään asiantuntijana kehittymisessä ja asiantuntijakeskustelun oppimisessa. Näiden tausta-ajatusten pohjalta opintojakso on pyritty suunnittelemaan ja toteuttamaan niin, että aktiivinen osallistuminen oppimisprosessiin on välttämätöntä ja prosessi itsessään on oppimisen kohteena. Opintojakson yksilö- ja ryhmäprosessit sekä niille ominainen vuorovaikutus pyrkivät näin ollen ilmentämään kollektiivisen ja avoimen asiantuntijuuden luonnetta, laatua ja kehittymistä (ks. kuvio 1).

\section{Asiantuntijuusseminaarin toteuttaminen}

\section{Työstetään seuraavia kysymyksiä}

a) Itsenäisesti (yksin):

- Mitä on minun asiantuntijuuteni/ osaamiseni (mallinnetaan kirjallisesti, kuvio tms.).

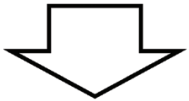

b) Itsenäisesti 4 - 5 hengen ryhmissä:

- "Miten minusta tuli minä" Miten asiantuntijuus on opettajaopintojen aikana kehittynyt.

- Mistä osa-alueista alani (opettajuuden) asiantuntijuus/osaaminen rakentuu (mallinnetaan, tehdään yhteinen jäsennys kirjallisesti, kuvio tms.).

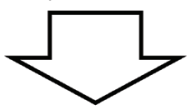

c) Seminaari-istunnoissa ( $5 \times 2$ tuntia):

- käsitellään ryhmien mallinnuksia opettajan asiantuntijuudesta sekä jäsennyksiä asiantuntijuuden kehittymisestä (alustus + yhteinen keskustelu)

- kussakin seminaari-istunnossa yksi ryhmä vastuussa palautteen antamisesta sekä alustajille että muille seminaarilaisille (palautteen kohteena erityisesti asiantuntijuusseminaarin vuorovaikutuksen laatu)

\section{Asiantuntijuuden tarkastelunäkökulmat}

(Hakkarainen, Palonen \& Paavola 2002, 451)

Asiantuntijuus

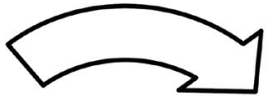

tiedonhankintana (mielensisäinen näkökulma)

kultuuriin osallistumisena (osallistumisnäkökulma)

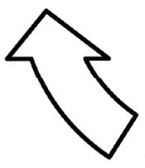

tiedonluomisena (luomisnäkökulma)

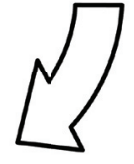

Kuvio 1. Kuvaus asiantuntijuusseminaarin toteuttamisesta 
Kurssin aluksi keskusteltiin asiantuntijuuden käsitteestä ja siitä että asiantuntijuus ei ole vain yksilön ominaisuus vaan yhteisöllisen vuorovaikutuksen tuote. Opiskelijoita myös kehotettiin lukemaan asiantuntijuutta ja osallistumisen merkitystä käsitteleviä artikkeleita (esim. Hakkarainen 2000; Tynjälä 2004).

\section{Tutkimuksen toteuttaminen}

Tutkimustehtävä ja -kysymykset. Tutkimuksemme tarkoituksena on sekä saada tietoa vuorovaikutuksen merkityksistä asiantuntijuudessa että kehittää vuorovaikutuksen ja asiantuntijuuden integrointiin tähtäävää oppimista ja opetusta. Tutkimuksen kontekstina on luokanopettajaopiskelijoiden opintojen loppuvaiheeseen sijoittuva asiantuntijuusseminaari. Tähän perustuen tutkimuksessa selvitetään,

1) miten orientaatio vuorovaikutukseen (osallistuminen, jakaminen, prosessimaisuus) näkyy ja miten se ymmärretään opettajaksi opiskelevien asiantuntijuusseminaarin itsearvioinneissa

2) millaisia suhtautumistapoja opiskelijoiden itsearvioinneissa ilmenee vuorovaikutukseen pohjautuvaa opintojaksoa kohtaan.

Aineisto ja analyysi. Tutkimusaineisto koostuu opiskelijoiden asiantuntijuusseminaarin päätyttyä kirjoittamista oman oppimisen itsearvioinneista $(\mathrm{N}=127)$. Aineisto on kerätty vuosina 2007-2008. Itsearviointityyppisessä kurssipalautteessa opiskelijoita pyydettiin ensiksi kuvaamaan opintojaksoa vertauksena ("tämä opintojakso oli minulle kuin...") ja perustelemaan kuvauksensa. Opiskelijoita pyydettiin myös kuvaamaan arvioitaan opettaja-asiantuntijuutensa kehittymisestä ("merkitse vasemmalta oikealle etenevään viivaan, joka kuvaa opettajan asiantuntijuutta, X siihen kohtaan, jossa koet olleesi ennen opintojakson alkamista ja $\mathrm{O}$ siihen, missä koet olevasi nyt”) sekä selittämään merkintöjensä "paikat". Lisäksi opiskelijoilta kysyttiin, mitkä tekijät opintojakson aikana vaikuttivat mahdolliseen kehittymiseen ja mikä askel heidän tulisi seuraavaksi ottaa asiantuntijana kehittymisessä. Opiskelijat saivat myös halutessaan kertoa muita kurssiin liittyviä asioita. Tutkimusaineistona käytettävän itsearviointipalautteen tarkoituksena on, että opiskelijoilta ei suoraan kysytä vuorovaikutukseen liittyviä merkityksiä vaan heiltä pyritään saamaan tietoa siitä, mitä vuorovaikutukseen pohjautuva oppimisprosessi on opettanut.

Tutkimustehtävä ja tutkimuskysymykset ovat luonteeltaan laadullisia. Aineiston sisällönanalyysi toteutetaan laadullisesti tarkastelemalla aineistoa tietystä teoreettis-metodologisesta näkökulmasta, jolloin kiinnitetään huomiota lähinnä siihen, mikä on teoreettisen viitekehyksen (tässä tutkimuksessa jaetun asiantuntijuuden ja vuorovaikutuksen näkökulmat) ja kysymyksenasettelun kannalta olennaista (ks. Alasuutari 1994, 30). Itsearviointiaineiston jokainen lomake analysoitiin kokonaisuutena, eli tutkimuskysymyksiin ei haettu vasta- 
uksia tietyistä lomakkeen kysymyksistä, vaan tulkinnat tarkasteltavista ilmiöistä tehtiin koko lomakkeen pohjalta.

Ensimmäisen tutkimuskysymyksen suuntaisesti pyritään pääsemään käsiksi ensinnäkin siihen, onko asiantuntijuus aineistosta nousevien kuvausten perusteella opiskelijan mielessä jotain itsessä vai asiantuntijoiden suhteissa rakentuvaa. Tätä pyrittiin selvittämään a) jakamisen ja osallistumisen näkökulmasta (vuorovaikutuksen merkitys asiantuntijuuden jakamisessa ja kehittymisessä) sekä b) prosessin näkökulmasta (miten opintojakson tarkoitus asiantuntijuuden prosessinomaisesta tarkastelusta ja syvenemisestä ymmärretään). Jakamisen ja prosessin näkökulmat kuvastavat opettajaksi kehittymisen keskeisiä tekijöitä: sekä kykyä aktiiviseen vuorovaikutteiseen toimintaan ja jaettuun tietämiseen että reflektiota, uskomusten ja toimintatapojen pohdintaa ja toiminnan perusteiden itsenäistä tai vuorovaikutteista tarkastelua (ks. Laine 2004, 17).

Jakamisen ja osallistumisen näkökulmasta aineistolle tehtiin sisällönanalyysi sen mukaan, miten vastaajien kuvauksissa tuli esille asiantuntijuuden ilmeneminen joko yksilön päänsisäisenä (orientaatio itsessä, minussa, olennaista antautumattomuus keskusteluun) tai vuorovaikutussuhteessa ilmenevänä ominaisuutena (orientaatio ryhmässä, meissä, olennaista antautuminen keskusteluun). Prosessin näkökulmasta aineistolle tehtiin sisällönanalyysi sen mukaan, miten kuvauksissa tuli esille opintojakson aikaisen prosessin ilmeneminen joko 1) oppimisen kertaluonteisuutena (orientaatio on itsessä ja oppiminen nähdään kertaluonteisena, "kerran kuultu on opittu"), 2) yksilön aktiivisena reflektiivisenä prosessina (oppija reflektoi aikaisempaa tietoa ja kokemusta sekä tiedostaa ja jäsentää omaa ajatteluaan ja toimintaansa) tai 3) vuorovaikutteisena, jatkuvasti syvenevänä ja kehittyvänä (orientaatio toisissa, vuorovaikutussuhteissa ja oppimisprosessin syvenemisessä). Jos edellä mainitut ulottuvuudet eivät tulleet kuvauksissa selkeästi esille, koodattiin kuvaukset omaan luokkaansa.

Toisen tutkimuskysymyksen suuntaisesti opiskelijoiden kuvauksia tarkasteltiin suhtautumistapojen näkökulmasta (millaisia tuntemuksia opintojakso ja sen toteutustapa herättivät). Sisällönanalyysissä pyrittiin löytämään tunneskaalan ääripäitä eli kuvauksia, joissa opintojaksoon liitetään selkeästi joko myönteisiä tai kielteisiä tuntemuksia. Mitä esimerkiksi ne opiskelijat, jotka "hehkuttavat" opintojakson hyvyyttä tai arvioivat sitä kielteisesti, kirjoittavat itsearviointeihinsa?

\section{Tulokset}

Orientaatio vuorovaikutukseen: Jakamisen ja osallistumisen näkökulmat. Aineistosta analysoitiin merkityksiä, jotka opiskelijoiden itsearvioinneissa ilmensivät käsityksiä tai kokemuksia osallistumisesta ja asiantuntijuuden jakamisesta eli siitä, kiinnittyykö asiantuntijuus yksilöön vai nähdäänkö se yksilöiden välisissä suhteissa rakentuvaksi ilmiöksi. 
Kuvauksissa, joissa orientaation tulkittiin opintojakson tavoitteiden mukaisesti olevan vuorovaikutussuhteissa (meissä), korostettiin ryhmän ja tietämyksen yhteisen prosessoinnin merkitystä ("kurssilla huomasin konkreettisesti, kuinka kollektiivinen älykkyys kehittyy"). Yhteisen tiedon rakentamisen koettiin usein johtavan merkittäviin siirtymiin pään sisäisestä toiminnasta suhteissa olemiseen sekä näkökulmien ja tiedon laajenemiseen ja täsmentymiseen. Seuraavat aineistoesimerkit havainnollistavat sitä, että pystyäkseen kirkastamaan omaa ajatteluaan, on hyvä keskustella asioista toisten kanssa. (Aineistoesimerkkien jäljessä oleva numero on opiskelijan kirjoitelman tunniste.)

"Tietorakenteet jäsentyivät. Hoksasin, että minun tulee kuulla myös muiden käsityksiä asiantuntijuudesta, jotta ymmärtäisin opettajuutta."(16)

“Opintojaksolla keskustelimme paljon ja "sosiaalinen paine" ajoi ajattelemaan asiaa. Omien ajatusten ja toisten ajatusten miettiminen oli antoisaa. Siitä syystä koen kehittyneeni jonkin verran asiantuntijuudessa." (27)

Asiantuntijaksi kehittymisen kannalta yhteisöön osalliseksi ja aktiiviseksi toteuttajaksi pääseminen on tärkeää (ks. Eteläpelto ym. 2005; Lave \& Wenger 1991). Tällöin on olennaista oivaltaa, että asiantuntijuus on vuorovaikutuksen tuloksena syntyvää suhteen ottamista toisten kasvatusalan asiantuntijoiden tietämiseen:

“Opintojakso vahvisti käsitystäni asiantuntijuudesta ja sen perimmäisestä olemuksesta. Sain myös varmuuden siitä, ettei asiantuntijuus ole yksin kehitettävä tai vastattava, vaan muodostuu osaamisen ja tiedon jakamisesta." (63)

[Opiskelija kuvaa, mitkä tekijät opintojakson aikana ovat vaikuttaneet janalla kuvattuun kehittymiseen] "Ryhmä: kanssaopiskelijat, heidän ajatuksensa sekä heiltä saamani vastakaiku omille ajatuksilleni. Konteksti, ryhmä merkityksen alleviivaaminen. Artikkeli. [Mikä askel sinun seuraavaksi asiantuntijana kehittymisessä tulisi ottaa?] Tulisi siirtyä käytäntöön, työelämään. Työelämässä pääsisin myös kollegiaaliseen opettajayhteisöön." (16)

Vuorovaikutusorientaation (yksilö suhteessa muihin) aikaansaaminen ja ylläpitäminen on haasteellista sekä ohjaajalle että opiskelijoille. Kokemukset opintojaksolla oppimisesta ja oppivaan yhteisöön osalliseksi tulemisesta näyttäisivätkin olevan vahvasti yhteydessä siihen, kuinka opiskelija kykenee panostamaan ja sitoutumaan opintojaksoon ja "antautumaan" yhteiseen keskusteluun. 
"Kirjaimellisesti yksi yliopiston kurssi muiden joukossa...suoritin sitä yhtenä muiden joukossa hieman puoliteholla." (14)

"Sai pohtia juurta jaksaen asioita, sai pohtia niitä muiden opiskelutovereiden kanssa, mikä lisäsi sekä mielenkiintoa että näkökulmia asioihin. Yleensä "saa" vain kuunnella luennoilla opettajan asiantuntijuudesta...todella antoisaa päästä itse pohtimaan ääneen ja perustelemaan näkökantaansa. [...] Ryhmä toimi hyvin, ja pidin siitä, että niin moni uskalsi osallistua keskusteluihin, meillä syntyi hyviä perusteluja vaativia eri mielipiteitä sisältäviä juttuja monista aiheista. Näin hedelmällisiin keskusteluihin pääsee harvoin osalliseksi!" (100)

Vaikka tutkimuksen kontekstina olevan opintojakson idea perustuu vuorovaikutukseen ja asiantuntijuuden jakamiseen, on aineistossa myös runsaasti kuvauksia, joissa jakamisen ideaa ei ole löydettävissä. Kuvauksissa, joissa orientaation tulkittiin olevan pääosin itsessä (minussa), asiantuntijuus ja siinä kehittyminen nähtiin ensisijaisesti yksilön ominaisuutena ("sain selkiytettyä omaa näkemystäni”"). Näissä kuvauksissa korostetaan omaa ajattelua, pohdintaa ja prosessointia sekä opintojakson antia lähinnä itselle:

"[- - - itse on vastuussa omasta asiantuntijuudestaan ja sen kehittymisestä.” (23)

“Opintojakso toi minulle tietoisuutta siitä, missä olen, ja se itsessään vei asiantuntijuuttani hiukan eteenpäin ja antoi minulle tietoisuutta siitä, miten tarkastelen tätä asiaa jatkossa." (17)

Kaikki eivät miellä vuorovaikutusta ("pelkkiä keskusteluja"), asiantuntijuuden tai siinä kehittymisen ulottuvuutena. Vaikka keskustelujen ja jakamisen kautta käsitys oman alan asiantuntijuudesta saattoi selkiytyä tai laajeta, ei vuorovaikutusta itsessään välttämättä ymmärretty keskeisenä prosessina tai substanssina asiantuntijana kehittymisessä. Erityisesti niissä kuvauksissa, joissa osallistumisen orientaation ja asiantuntijana kehittymisen tulkittiin olevan pääosin itsessä, ei keskusteluilla ja ymmärryksen yhteisellä jakamisella nähty olevan kovin suurta merkitystä tai arvoa:

"Mielestäni siihen, että en siirtynyt viivalla [asiantuntijuuden kehittymistä kuvaava jana], vaikuttaa se, että emme käyneet itse asiantuntijuuteen liittyviä seikkoja vaan keskustelimme vain siitä, mitä nämä ovat." (09)

"Olisin toivonut muutakin sisältöä kuin pelkkiä keskusteluja." (37) 
Jos vuorovaikutusta ei nähdä asiantuntijuuden ulottuvuutena, on ymmärrettävää, että asiantuntijuudesta keskustelun ei myöskään nähdä kehittävän asiantuntijuutta sinänsä. Erityisesti seuraavissa esimerkeissä (kirjoitelmat 04 ja 21) opiskelijat kokevat tarvitsevansa asiantuntijana kehittymiseen erityisesti kasvatustieteen ja opetettavien aineiden substanssien opiskelua, vaikka heidän kuvauksissaan näkyykin selvästi se, että näkökulma oman alan asiantuntijuuteen on auennut ja jäsentynyt juuri yhteisen jakamisen ja vuorovaikutuksen tuloksena. Vaikka vuorovaikutus näyttäisi olleen ymmärryksen laajenemisen avain, on kiinnostavaa, että asiantuntijuus kiinnitetään alakohtaiseen tietoon ja vuorovaikutusta tai jakamista ei nähdä varsinaisen asiantuntijuuden ulottuvuutena:

“En koe, että oma asiantuntijuuteni kauheasti lisääntyi kurssin aikana. Mielestäni asiantuntijuuden lisääntymiseen olisi tarvittu pääasiassa kasvatustieteen tai ainekohtaisten sisältötietojen opettamista. Tämän kurssin anti asiantuntijuuden osalta oli kuitenkin siinä, että se sai silmät avautumaan siitä, mitä se asiantuntijuus (kasvatusalalla) ylipäätään on. [- - - Erityisesti, että saatiin keskustella niin paljon [on vaikuttanut kehittymiseen kurssilla]. Kurssin aluksi ymmärsin asiantuntijuuden lähinnä opettamiseksi ja opetustyöksi, mutta yhteisten keskustelujen jälkeen ajattelen siitä enemmän luokanopettajina toisille kasvatusalan ammattilaisille puhumisena/opettamisena. Oli hyödyllistä kuunnella myös niin paljon "vertaistensa" ajatuksia. [Mikä askel sinun seuraavaksi asiantuntijana kehittymisessä tulisi ottaa?] Nyt sitten tietoa, joka tekee minusta asiantuntijan, täytyisi lisätä. Eli siis kasvatustieteitä ja ainekohtaista tietoa lisää vaan.” (04)

"Koen, että kurssin aikana asiantuntijuuteni ei välttämättä ole edennyt/kehittynyt enempää kuin muutoinkaan opintojen puitteissa. Sen sijaan se on jäsentynyt hurjasti." (21)

Se että vuorovaikutusta ei nähdä varsinaisena asiantuntijuutena, voi selittyä esimerkiksi sillä, että vuorovaikutus on osin luonteeltaan hiljaisen tiedon kaltaista osaamista (ks. Kostiainen 2003, 40-47), joka on jo itsessään niin implisiittisesti sitoutunut toimintakäytänteisiin, että sen merkitystä tietoisena ja tavoitteellisena keinona asiantuntijuuden laadun syvenemisessä ja kehittymisessä on vaikeaa nähdä. Toisaalta vuorovaikutus on konkreetti ja aina läsnä oleva, toisaalta abstrakti osaamisen ulottuvuus, jonka osuutta voi olla vaikea täsmentää oppimisprosesseissa. Se että ihminen ei aina kykene ilmaisemaan, mihin hänen osaamisensa lopulta perustuu, ei välttämättä johdu esimerkiksi puutteellisesta kyvystä selittää asioita vaan siitä, että osaaminen ei perustu riittävään tietoon (Ryle 1961; ks. myös Kostiainen 2003, 41). Opiskelijat voivat 
ymmärtää vuorovaikutusosaamisen enemmänkin taitona, käytänteinä tai välineenä kuin teoreettisena tietona ja sisältönä (ks. Isotalus 2006, 75), jolloin heillä ei luonnollisestikaan ole valmiuksia jäsentää vuorovaikutuksen moniulotteisia merkityksiä asiantuntijuudessa.

Orientaatio vuorovaikutukseen: Prosessi. Aineistosta tarkasteltiin myös sitä, kuinka opiskelijat kuvaavat vuorovaikutukseen pohjautuvan oppimisprosessin luonnetta. Huomiota kiinnitettiin siihen, kuvastavatko itsearvioinnit ajattelutapaa, jossa tieto ja tietäminen nähdään kertaluonteisena tai määrällisesti kasautuvana vai nähdäänkö tieto ja tietäminen reflektoivana, omaa tai vuorovaikutuksessa syntyvää ajattelua ja toimintaa pohtivana prosessina.

Joidenkin opiskelijoiden kuvauksista välittyi se, että he eivät kokeneet saaneensa uutta tietoa. Prosessin näkökulmasta katsottuna niiden tulkittiin ilmentävän oppimisen kertaluonteisuutta.

"Onhan se mukavaa keskustella yhdessä, mutta en nyt tiedä tuliko jaksolla mitään kovin uutta ja ihmeellistä. Asioita on tankattu muilla kursseilla, mutta nyt siihen liitettiin termi ASIANTUNTIJUUS." (34)

"Tunnin mittaiset alustukset tuntuivat jo hieman puulta, koska ensimmäisen jälkeen sekä alustukset että keskustelu suurelta osin toistivat samaa asiaa." (29)

Arvioinneissa, joissa reflektoivan ja jatkuvan prosessin ajatus tuli esille, oli prosessin fokus enimmäkseen oman pään sisäisessä, yksilöllisessä prosessoinnissa, kuten seuraavissa esimerkeissä:

"Perustelujen löytäminen omalle toiminnalle ja ajattelulle vie mielestäni paljon eteenpäin asiantuntijuudessa. Omat perustelut selkiytyivät paljon kurssin aikana."(41)

"Kuvasin kehitystä lähinnä tiedostamisen tasolla. Kehityin asiantuntijana paljon, koska heräsin oikeasti ja vakavasti pitkästä aikaa miettimään opettajan asiantuntijaroolia, ja mitä kaikkea siihen sisältyy. Kehityin oman asiantuntijuuteni hahmottamisessa ja tiedostamisessa." (47)

Joissakin kuvauksissa tuli selvästi esille toisten oppijoiden merkitys oppimisprosessille eli oppimisen yhteinen ja yhteisöllinen luonne. Tällaisia pohdintoja kuvaavat seuraavat esimerkit:

"Yhdessä ja erikseen tapahtunut pohdiskelu liittyen asiantuntijuuteen ja sen mukanaan tuoma lisääntynyt ymmärrys sekä itse aiheesta että omasta ja muiden ymmärryksestä.” (81) 
"Ennen vanhaan löytöretkeilijöillä oli jonkinlainen taito lähteä merelle. Matkan myötä heidän asiantuntijuutensa kehittyi yhteistyöllä, uusien maiden löytämisellä ym. Näen samoja piirteitä tällä kurssilla, jokaisella oli jonkunlainen pohja ennen jaksoa ja jakson myötä syvennettiin, laajennettiin ja kehitettiin omia asiantuntijuuspiirteitämme." (76)

"Ehdottomasti ne [tekijät, jotka vaikuttivat asiantuntijuuden kehittymiseen opintojakson aikana] olivat jaetut kokemukset, erilaiset näkökannat ja mielipiteet. Minusta oli tärkeää, että työstin asiaa prosessinomaisesti: ensin yksin, sitten ryhmässäni (5hlöä) ja lopuksi koko demoryhmän kanssa. Tuntui hyvältä, kun pienryhmäni todella työsti aihetta ja tehtävää. Pienryhmässä saa erilailla asioita esiin kuin suuressa. Ne eivät silti ole poissulkevia asioita, vaan koen, että oli hyvä olla sekä pienessä että isossa ryhmässä jaettavaa keskustelua.”(36)

Opettajaksi opiskelevien on erityisen tärkeää ymmärtää, että oppiminen ja tietäminen on jatkuva prosessi eikä niin sanottua kappaletavaraa (ks. Koivunen 2005, 34; Weick 1995, 43). Opiskeluvaiheessa onkin pyrittävä ravistelemaan ja kyseenalaistamaan opiskelijoiden melko tyypillistä minän näkökulmasta lähtevää "tämän minä tiedän jo entuudestaan" -ajattelumallia. Tämä voi osaltaan olla seurausta siitä, että opettajan työ tuntuu tutulta. Opettajan, erityisesti, on oivallettava, että tietoa konstruoidaan ja lähestytään aina eri tavalla eri ihmisten kesken ja opettajan tulisi olla nimenomaan kiinnostunut toisten - oppilaidensa keskinäisestä tiedonmuodostuksesta ja ymmärryksen rakentamisesta. Vain tällä tavoin opettaja voi päästä kiinni oppilaiden tapaan ajatella.

Prosessin siirrettävyys. Tutkimuksemme kohteena olevan opintojakson toteuttamisessa on lähtökohtana pidetty sitä, että oppimisprosessi on avain opitun siirrettävyyteen, eivät niinkään yksittäiset taidot ja tiedot, joiden ajatellaan sellaisenaan olevan siirrettäviä (ks. Whitston 1998, 317). Vaikka tämän tutkimuksen asetelma ja aineisto eivät varsinaisesti anna mahdollisuutta tarkastella opitun siirrettävyyttä, on opiskelijoiden käsityksissä runsaasti viittauksia myös opitun prosessin siirrettävyydestä ja soveltumisesta työelämään:

”Huomaa, kuinka tärkeää olisi jatkossakin jakaa asioita kollegoiden kanssa toisia tukien, vahvistaen ja rikastaen. Kollegoiden merkitys nousi merkittäväksi jälleen kerran.” (52)

"[- - - ] tuntuu, että takaraivoon jäi myös paljon sellaista, mistä jatkossa on hyötyä!!" (61)

"Ennen opintojakson alkua en kokenut olevani asiantuntija, vaikka opintoni alkavatkin olla loppusuoralla. Nyt ymmärrän asiantuntijuu- 
den olemusta mielestäni paremmin; se ei koskaan ole täydellinen, eikä kahden ihmisen näkemys asiantuntijuudesta ole samanlainen. [- - ] Nyt pystyn kuitenkin omalla toiminnallani ehkä edistämään omaa asiantuntijuuttani parempaan suuntaan, ja uskallan hakea jaettua asiantuntijuutta myös opettajainhuoneesta." (98)

Kiinnostavaa kurssin antiin liittyneissä arvioinneissa oli se, että monet opiskelijat kokivat saaneensa itsevarmuutta, luottamusta itseensä, uskoa omaan alaansa ja näkemystä omasta vastuusta asiantuntijuuden kehittämisessä:

"Kurssilta sai myös itsevarmuutta, sillä näki, että muutkin kamppailevat samanlaisten ongelmien/asioiden kanssa kuin minä." (27)

"Toisaalta oli mukava huomata, että jossain asioissa löytyi paljon yhteistä muiden kanssa, mikä taas antaa luottamusta siihen, että olen kehittymässä jonkin tietyn alan asiantuntijaksi” (41)

"Hyödyllinen ja tarpeellinen kurssi! Auttoi hahmottamaan sitä tosiasiaa, että itse on vastuussa omasta asiantuntijuudestaan ja sen kehittymisestä.” (23)

Luottamusta ja varmuuden tunnetta pidetään olennaisina tekijöinä asiantuntijaksi kasvamisessa. Esimerkiksi Isopahkala-Bouret $(2008,89)$ puhuu asiantuntijuuden kokemisen emotionaalisesta puolesta, johon liittyy luottamuksen ja varmuuden tunne omasta osaamisesta ja kyvystä toimia. Numminen (1995) puolestaan korostaa tulevan opettajan vahvaa itsetuntoa ja tietoa tehtävänsä tärkeydestä.

Suhtautuminen opintojaksoon. Aineistosta tarkasteltiin, mitä myönteisiä ja kielteisiä suhtautumistapoja vuorovaikutukseen pohjautuvasta opintojaksosta välittyi ja mihin ne kohdistuvat. Kurssin toteutustapa sai arvioinneissa lähes varauksettomasti kiitosta:

"Oli oikein mukava kurssi ja ilmapiiri ryhmässä oli ihana!" (04)

"Aivan tosi mielettömän hyvä ja opettavainen kurssi. Tykkäsin siitä sellaisenaan!" (21)

”Hyvä, ajattelemaan herättävä tapa järjestää ko. kurssi. ”(38)

’Loistavaa, että tiettyä yhtä asiaa/käsitettä käydään läpi näin perin pohjin. Silloin siitä saa oikeasti paljon irti." (119)

Osalla oli kurssin alussa epäilyjä sisällön, erityisesti samasta teemasta käytävien keskustelujen kantavuuden ja antoisuuden, suhteen. 
"Alkuun kritisoin kurssia melko kiihkeästikin: onhan tällaista keskustelua ennenkin käyty. Nyt kun kurssi on ohi, olen ymmärtänyt, että ei tällaista keskustelua ole ennen käyty, joka olisi näin selkeästi jäsentänyt asiantuntijuuttani.”(58)

Keskustelut myönteisesti kokeneiden opiskelijoiden arvioinneista välittyi sekä innostuneisuus että vahva osallisuuden ja yhteisyyden kokemus, mikä osaltaan kuvastaa oivallusta asiantuntijuuden yhteisestä jakamisesta.

"Suurempi vaikutus on ollut keskustelujen anti ja ihmisten osallistuminen, hyvin syvällisesti." (82)

"Ensimmäinen kurssi, jossa ihan oikeasti pääsi keskustelemaan hyvin olennaisista asioista ja pohtimaan juttuja, joita ei kirjoista opeteta." (124)

Jotkut opiskelijat kritisoivat osallistumisen epätasaisuutta ("harmittaa, että keskustelu jakaantui epätasaisesti"). Huomattavaa oli myös se, että osassa arvioinneista välittyi vahva ahdistus siitä, että kurssilla on osallistuttava ja puhuttava:

"Itseä ahdisti se, että on "pakko" puhua, vaikka pelkkä kuuntelu antaa itselle yhtä paljon tai jopa enemmän.” (112)

"Vaikka asiantuntija ei voi olla yksin, ketään ei saisi pakottaa puhumaan. Se estää ajattelua ja oppimista. Välillä ahdisti paine siitä, että kaikkien pitäisi puhua ja olla äänessä." (31)

Jotta jaettua asiantuntijuutta voi syntyä, on yksilöiden haluttava ja osattava jakaa tietoa muiden kanssa (Koivunen 2005, 43). On kuitenkin tyypillistä, että opiskelijaryhmissä keskustelu voi jakautua epätasaisesti ja jotkut voivat jopa olla näkyvästi osallistumatta koko opintojakson ajan. Koska opintojakson tavoitteissa ja toteuttamistavassa on vuorovaikutukseen osallistumisen merkitys hyvin korostunut, on olennaista miettiä, mitä osallistumisella ymmärretään ja mitä sen ilmenemisestä ajatellaan. Pelkkä aktiivisuus ja osallistuminen ei takaa vielä oppimista, eikä passiivisuus tarkoita oppimattomuutta (Holt-Reynolds 2000, 21-22). Osa osallistumattomista opiskelijoista on ikään kuin "oppimisen todistajia" (witness learners), jotka eivät osallistu aktiivisesti, mutta jotka seuraavat kuitenkin prosessia ja kokevat oppivansa, kuten seuraavassa esimerkissä ilmenee:

"Keskustelut olivat todella mielenkiintoisia ja vaikka en itse aina osallistunut niin aktiivisesti, se johtui lähinnä siitä, että halusin vain kuunnella ja pyöritellä muiden kommentteja ja ammentaa niistä itsel- 
leni mahdollisimman paljon hyödyllistä tietoa ja uusia näkökulmia." (28)

Tämä kuvastaa sitä, että orientaatio voi olla "meissä" ja "jakamisessa", vaikka itse ei osallistuisikaan aktiivisesti. Oleellista on siis oppijan kokemus osallisuudesta, ei pelkästään se, miten hän ulkoisesti havaittavalla tavalla osallistuu. Näin ollen osallistumisen voidaan ymmärtää pitävän sisällään sekä näkyvän osallistumiskäyttäytymisen että näkymättömän, päänsisäisen prosessoinnin, jotka molemmat rakentavat osallisuutta. Täysin osattomaksi oppimisprosessista jää tällöin passiivinen oppija, joka ei pysty tai ei kiinnostu olemaan mukana yhteisessä asian käsittelyssä. Toisaalta on aiheellista kysyä, voisiko opettajaksi opiskelevilta jopa vaatia sekä aktiivista kuuntelemista että ajatustensa esille tuomista pyrittäessä oppimaan jaetun asiantuntijuuden ideaa.

\section{Lopuksi}

Muuttuvassa yhteiskunnassa uuden tiedon ja ajattelutapojen luominen on opetusalalla työskenteleville elintärkeää. Uuden ymmärryksen aikaansaamisessa kollektiiviset prosessit ovat välttämättömiä. Niiden ymmärtäminen edellyttää, että opimme tuntemaan toisten ihmisten kyseiselle tiedonalalle luomia tiedollisia polkuja ja suhteuttamaan niihin omaa tietoamme ja ymmärrystämme (Hakkarainen 2003). Nämä kollektiiviset prosessit on mahdollista tehdä näkyviksi ja tietoisiksi vuorovaikutuksessa.

Tutkimuksessamme opiskelijoiden itsearvioinneista välittyi selvästi jakamisen orientaatio asiantuntijuuteen. Oppiminen myös nähtiin enimmäkseen aktiivisena reflektiivisenä prosessina. Oppimisen kuvaaminen henkilökohtaisena, oman ajattelun tarkasteluna, oli selvästi tutumpaa. Sellaisia oppimisen kuvauksia, joissa selkeästi kurottauduttiin vuorovaikutteisesti toisiin tai yhteiseen prosessiin, oli itsearviointiaineistossa vähemmän. Kiinnostavaa oli myös se, että oppimisen kuvauksissa saattoi selvästi puuttua asiantuntijuuden jakamisen ajatus, mutta toisaalta prosessista välittyi selkeästi reflektiivinen, omaa ajattelua ja toimintaa pohtiva kuva. Tämä kuvastaa osaltaan sitä, miten oppiminen näyttäytyy yksilöllisenä toimintana. Myös jaetussa asiantuntijuudessa tasapaino yksilöllisyyden ja kollektiivisuuden välillä on horjuva ja jatkuvasti uudelleen neuvoteltava asia (Koivunen 2005, 43).

Itsearviointien perusteella erityisesti vertaisryhmien hyvä ja turvallinen ilmapiiri sekä yhteisiin keskusteluihin ja jakamiseen perustuva työskentelytapa edistivät oppimista: niiden myönteistä merkitystä korostettiin vahvasti. Tätä tukee osaltaan Laineen $(2004,232)$ tutkimus, jonka mukaan luokanopettajaksi opiskelevat pitivät koulutuksen ilmapiiriä, osallistumistapaa ja vertaisryhmäkokemuksia oman ammatillisen kehittymisensä kannalta merkityksellisinä opettajankoulutuksen toteuttamiseen liittyvinä tekijöinä. 
Asiantuntijaidentiteetin rakentamiseen tarvitaankin sekä reflektiivistä tietämistä, jonka avulla omaa toimintaa voidaan tarkastella, että yhteisöllisyyttä, johon kiinnittyä ja johon peilata omaa identiteettiä. Ammatillisen kasvun tukemisessa on vertaisryhmällä ja koko oppimisyhteisöllä tärkeä merkitys. Tutkimuksemme tulokset tukevat Laineen $(2004,233)$ käsitystä siitä, että vertaisryhmän yhteisyyden kokemukset vahvistavat yksittäistä yksilöä, mikä liittää tiukemmin yhteen ja mahdollistaa kollektiivisen kokemuksellisen yhteisöllisyyden jakamisen. Opettajuutta ei voi olla ilman toista tai toisia, ja se toteutuu aina suhteessa toisiin. Tutkimus vahvistaakin käsitystä siitä, että oppimisprosessien tulisi olla jo peruslähtökohdiltaan vuorovaikutussuhteissa toteutuvia. Näinhän se periaatteessa aina onkin, mutta tulokset haastavat pohtimaan, ymmärretäänkö oppiminen suhteissa tapahtuvaksi ja miten opiskelijoita voisi tavoitteellisesti ohjata tarkastelemaan ja arvioimaan opettajuutta vuorovaikutussuhteissa toteutuvana professiona.

Tämän tutkimuksen epistemologisena oletuksena on pidetty sitä, että tutkittavien ihmisten kokemukset ja käsitykset kuvaavat heitä ympäröivää todellisuutta ja sille annettuja merkityksiä, mistä todisteina toimivat ihmisten omat kertomukset ja käsitykset, joita tavoiteltiin itsearviointikyselyllä. Tällöin on tärkeää pohtia, mitä aineisto ja sen keräämisen tapa vaikuttavat saatuun tietoon ja tuloksiin. Itsearvioinnit kirjoitettiin yksin, mikä myös saattaa ohjata ajattelemaan oppimista yksilöllisenä prosessina. Kirjoitusgenrenä itsearviointiin sisältyy pohtiva, minäkeskeinen kirjoittaminen. Toisenlaista aineistoa olisi voitu saada ryhmäpohdintatehtävällä. Analyysiin liittyy myös tulkintaa koskeva haaste. Saman oppijan itsearvioinnista voitiin tulkita monenlaisia orientaatioita. Hän saattoi toisaalta kirjoittaa antoisasta, pohtivasta keskustelusta, mutta myös siitä, ettei kokenut saavansa mitään uutta. Sinänsä ristiriitaiset ainekset ajattelussa voidaan nähdä siihen olennaisesti kuuluvina (ks. Billig \& al. 1988). Koulutuksessa nämä ristiriitaisuudet tulee nostaa tarkastelun kohteeksi, mikä osaltaan voisi edistää oppijoiden vuorovaikutustiedon kehittymistä.

Jatkossa tutkimuksen kohteeksi tulisi nostaa asiantuntijakeskustelussa toteutuva vuorovaikutusprosessi. Sitä tutkimalla voidaan selvittää, millaista asiantuntijapuhetta ja asiantuntijuutta opiskelijat tuottavat ryhmäkeskustelussaan. Näin päästäisiin selvittämään myös sitä, mitä viestinnällisiä valmiuksia opiskelijoilla on osallistua ja tuottaa kollektiivista asiantuntijuutta keskustelussa. Jatkotutkimusta tarvittaisiin myös siitä, mitä näkemyksille asiantuntijuudesta, sen luonteesta ja hyödyntämisestä tapahtuu opiskelijoiden siirtyessä opettajan työhön. Miten opiskelun aikana oivalletut yhteisöllisen jakamisen ja prosessoinnin merkitykset nähdään työelämässä, miten ne muuttuvat ja miten ne konkretisoituvat työkäytänteissä?

Tässä tutkimuksessa opintojensa loppuvaiheessa olevien luokanopettajaopiskelijoiden puheessa heijastuvat sekä opiskelijan että alkavan asiantuntijan näkökulmat, joihin koulutuksessa on mahdollisuus tarttua. Opettajaksi opiske- 
levan on tärkeää oivaltaa, että valmistuttuaan hänen ei asiantuntijana tarvitse tukeutua vain omaan, ehkä vielä epävarmaan, vaan koko asiantuntijakulttuurin tukea antavaan ääneen (ks. Hakkarainen 2003, 389). Opettajan työ on nyt ja tulevaisuudessa mitä suurimmassa määrin työtä, jota kukaan ei voi tehdä yksin - ainakaan asiantuntevasti.

\section{Kirjallisuus}

Alasuutari, P. 1994. Laadullinen tutkimus. Tampere: Vastapaino.

Alexander, P. A. \& Murphy, P. K. 1999. Nurturing the seeds of transfer: a domain- specific perspective. International Journal of Educational Research 31, 561-576.

Billig, M., Condor, S., Edwards, D., Gane, M., Middleton, D. \& Radley, A. 1988. Ideological dilemmas: a social psychology of everyday thinking. London: Sage.

Brown, A. 1998. Designing effective learning programs. Teoksessa W. J. Nijhof \& J. N. Streumer (toim.) Key qualifications in work and education. Dordrecht: Kluwer, 165-186.

Bullough, R. V. Jr. \& Baughman, K. 1995. Changing contexts and expertise in teaching: First-year teacher after seven years. Teaching \& Teacher Education 11 (5), 461-477.

Dannels, D. P. 2001. Time to speak up. A theoretical framework of situated pedagogy and practice for communication across the curriculum. Communication Education 50 (2), 144-158.

Eräsaari, R. 2002. Avoimen asiantuntijuuden analytiikka. Teoksessa I. Pirttilä \& S. Eriksson (toim.) Asiantuntijoiden areenat. Jyväskylä: Sophi, 21-58.

Eteläpelto, A., Littleton, K., Lahti, J. \& Wirtanen, S. 2005. Students' accounts of their participation in an intensive long-term learning community. International Journal of Educational Research 43, 183-207.

Gerlander, M. \& Kostiainen, E. 2005. Jännitteisyys opettajan ja oppijan vuorovaikutussuhteessa. Teoksessa T.-R. Välikoski, E. Kostiainen, E. Kyllönen \& L. Mikkola (toim.) Prologi. Puheviestinnän vuosikirja 2005, 68-87. Jyväskylä: Prologos ry.

Gruber, H., Law, L., Mandl, H. \& Renkl, A. 1996. Situated learning and transfer. Teoksessa P. Reimann \& H. Spada (toim.) Learning in humans and machines. Towards an interdisciplinary learning science. Oxford: Pergamon Press, 168-188.

Hakkarainen, K. 2000. Oppiminen osallistumisen prosessina. Aikuiskasvatus 20, 84-98.

Hakkarainen, K. 2003. Kollektiivinen älykkyys. Psykologia 6, 384-401. 
Hakkarainen, K. 2005. Asiantuntijuus ja oppiminen työelämässä psykologisia näkökulmia. Puheenvuoro Osaaminen murroksessa.

Työelämälähtöisen osaamisen tunnistaminen ja tunnustaminen -seminaarissa 12.4.2005 Helsinki. Saatavilla www-muodossa: <URL:http://www.helsinki.fi/science/networkedlearning/material/ HakkarainenEsitelma2005a.pdf/>. Viitattu 11.8.2009.

Hakkarainen, K. \& Paavola, S. 2006. Kollektiivisen asiantuntijuuden mahdollisuuksia ja rajoituksia - kognitiotieteellinen näkökulma. Teoksessa J. Parviainen (toim.) Kollektiivinen asiantuntijuus. Tampere: Tampere University Press, 214-272.

Hakkarainen, K., Palonen, T. \& Paavola, S. 2002. Kolme näkökulmaa asiantuntijuuden tutkimiseen. Psykologia 37 (6), 448-464.

Holt-Reynolds, D. 2000. What does teachers do? Constructive pedagogies and prospective teachers' beliefs about the role of a teacher. Teaching and Teacher Education 16 (1), 21-32.

Hunt, S. K., Simonds, C. J. \& Cooper, P. J. 2002. Communication and teacher education: Exploring a communication course for all teachers. Communication Education 51 (1), 81-94.

Hurma, T. (Ikonen, P., Kainulainen, J., Kostiainen, E., Ovaska, M., Rautiainen, M., Salminen, S. \& Salo, O.-P.) 2009. Juna meni jo - millä asemalla seisot opettajankoulutus? KeVer-verkkolehti 8 (1). Saatavilla www-muodossa: <URL:http://ojs.seamk.fi/index.php/kever/article/ view/389/451/>. Viitattu 5.8.2009.

Isopahkala-Bouret, U. 2008. Asiantuntijuus kokemuksena. Aikuiskasvatus 2, 84-93.

Isotalus, P. 2006. Puheviestintä tietona. Virkaanastujaisesitelmä. Teoksessa T.-R. Välikoski, E. Kostiainen, E. Kyllönen \& L. Mikkola (toim.) Prologi. Puheviestinnän vuosikirja 2006, 72-81. Jyväskylä: Prologos ry.

Karila, K., Alasuutari, M., Hännikäinen, M., Nummenmaa, A. \& RaskuPuttonen, H. (toim.) 2006. Kasvatusvuorovaikutus. Tampere: Vastapaino.

Koivunen, N. 2005. Miten kollektiivinen asiantuntijuus organisoituu? Hallinnon tutkimus 24 (3), 32-45.

Kostiainen, E. 2003. Viestintä ammattiosaamisen ulottuvuutena. Jyväskylän yliopisto. Jyväskylä Studies in Humanities 1.

Laine, T. 2004. Huomisen opettajat. Luokanopettajakoulutus ammatillisen identiteetin rakentajana. Acta Universitatis Tamperensis 1016.

Lave, J. \& Wenger, E. 1991. Situated learning. Legitimate peripheral participation. Cambridge: Cambridge University Press.

Numminen, J. 1995. Opettajapersoonallisuuden kasvattaminen. Teoksessa E. Korpinen (toim.), Opettajaksi oppimaan - kasvattajaksi kasvamaan. Jyväskylän yliopisto, opettajankoulutuslaitos. Opetuksen perusteita ja käytänteitä 7, 29-35.

Raivola, R. 2000. Tehoa vai laatua koulutukseen? Porvoo: WSOY.

Rautiainen, M. 2008. Keiden koulu? Aineenopettajaksi opiskelevien käsityksiä koulukulttuurin yhteisöllisyydestä. Jyväskylän yliopisto. Jyväskylä Studies in Education, Psychology and Social Research 350. 
Renkl, A., Mandl, H. \& Gruber, H. 1996. Inert knowledge: analyses and remedies. Educational Psychologist 31 (2), 115-121.

Ryle, G. 1961. The concept of mind. 3. painos. London: Hutchinson.

Tynjälä, P. 2004. Asiantuntijuus ja työkulttuurit opettajan ammatissa. Kasvatus 35 (2), 174-190.

Valkonen, T. 2003. Puheviestintätaitojen arviointi. Näkökulmia lukiolaisten esiintymis- ja ryhmätaitoihin. Jyväskylän yliopisto. Jyväskylä Studies in Humanities 7.

Välijärvi, J. 2006. Kansankynttilästä tietotyön ammattilaiseksi. Opettajan työn yhteiskunnallisten ehtojen muutos. Teoksessa A. R. Nummenmaa \& J. Välijärvi (toim.) Opettajan työ ja oppiminen. Jyväskylän yliopisto. Koulutuksen tutkimuslaitos, 9-26.

Weick, K. E. 1995. Sensemaking in organizations. Thousand Oaks: Sage.

Wenger, E. 1999. Communities of practice: learning, meaning, and identity Cambridge: Cambridge University Press.

Whitston, K. 1998. Key skills and curriculum reform. Studies in Higher Education 23 (3), 307-319. 